\title{
Food Sources and Accessibility and Waste Disposal Patterns across an Urban Tropical Watershed: Implications for the Flow of Materials and Energy
}

\author{
$\underline{\text { Diana C. Garcia-Montiel }}{ }^{1}, \underline{\text { Julio C.Verdejo-Ortiz }}^{2}, \underline{\text { Raul Santiago-Bartolomei }}^{2}$, Cristina P. Vila-Ruiz $^{3}, \underline{\text { Luis Santiago }}^{2}$ and Elvia \\ Melendez-Ackerman ${ }^{3,4}$
}

\begin{abstract}
Appraising the social-ecological processes influencing the inflow, transformation, and storage of materials and energy in urban ecosystems requires scientific attention. This appraisal can provide an important tool for assessing the sustainability of cities. Socioeconomic activities are mostly responsible for these fluxes, which are well manifested in the household unit. Human behavior associated with cultural traditions, belief systems, knowledge, and lifestyles are important drivers controlling the transfer of materials throughout the urban environment. Within this context, we explored three aspects of household consumption and waste disposal activities along the Río Piedras Watershed in the San Juan metropolitan area of Puerto Rico. These included: the source of food consumed by residents, recycling activities, and trends in connection to the municipality's sewerage system. We randomly interviewed 440 households at 6 sites along the watershed. We also conducted analysis to estimate accessibility to commercial food services for residents in the study areas. Our surveys revealed that nearly all interviewed households ( $97 \%)$ consumed products from supermarkets. In neighborhoods of the upper portion of the watershed, where residential density is low with large areas of vegetative cover, more than $60 \%$ of residents consumed food items cultivated in their yards. Less than $36 \%$ of residents in the in densely urbanized parts of the lower portion of the watershed consumed items from their yards. Accessibility to commercial stores for food consumption contrasted among study sites. Recycling activities were mostly carried out by residents in the lower portion of the watershed, with better access to recycling programs provided by the municipality. The surveys also revealed that only 4 to $17 \%$ of residences in the upper watershed are connected to the sewerage system whereas the large majority uses septic tanks for septic water disposal. For these residents wastewater from house maintenance is disposed of directly into the environment. In the lower portion of the watershed all residents were connected to the sewerage system. Our study suggests there is a need to understand human behavioral attitudes in the acquirement and processing of resources, as a tool to generate informed-based strategies promoting sustainable consumption and disposal patterns.
\end{abstract}

Key Words: household; nutrient cycling; San Juan ULTRA; social-ecological systems; urban biogeochemistry; urban ecology; urban metabolism; watershed

\section{INTRODUCTION}

The flow of materials and energy through an urban ecosystem occurs mostly through human socioeconomic activities that transform and transfer food, goods, water, and energy (Decker et al. 2000). Because human-biophysical interactions in cities are very dynamic, they are central to the basic functional properties of urban ecosystems (Pickett et al. 2001, Kaye et al. 2006). In addition, human activities in the urban environment are massively concentrated, thus resulting in the intensification of transformation processes, including biogeochemical cycling of nutrients (Groffman et al. 2004, Kaye et al. 2006) and the increased accumulation of waste products (Kennedy et al. 2007). Urban ecosystems are also dependent on an enormous inflow of materials and energy to maintain the dynamic of production and consumption activities (Kennedy et al. 2007).

Understanding and quantifying the processes of inflow, transformation, and storage of materials that result from the use of resources is an important aspect of urban ecology that requires scientific attention. This systems approach has been suggested as an important tool for assessing the sustainability of cities (Baker et al. 2007, Kennedy et al. 2007, Codoban and Kennedy 2008). Understanding how materials and energy are processed as the consequence of socioeconomic activities would lead to educated- based strategies promoting sustainable production and consumption patterns, and more informed decision making regarding resource use, waste reduction, and pollution management (Baker et al. 2007, Codoban and Kennedy 2008).

Households are responsible for a considerable amount of the flow of material and energy within cities (Kaye et al. 2006, Baker et al. 2007). Human consumption behaviors associated with cultural traditions, belief systems, knowledge, and life styles (Fig. 1) are likely important drivers determining these inflows, as well as the way these entries are processed and stored throughout urban ecosystems. This set of behavioral attitudes determines decisions such as household size, housing choices, including the proportion of grey to green area, management alternatives such as species composition of yards and lawn fertilization, consumption patterns, waste disposal and recycling activities (Fig. 1). Human decisions manifested in the household unit determine patterns of resource acquirement, i.e., inputs and of disposal, i.e., outputs. Therefore, to understand processes of material transfer from a social-ecological perspective requires an approach that considers the human behavior structure as an underlying mechanism explaining mass and energy fluxes (Fig. 1, Chowdhury et al. 2011). The household system has been suggested (Liu et al. 2003, Grove et al. 2006, Baker et al. 2007) as the most appropriate unit of

${ }^{1}$ Institute For Tropical Ecosystem Studies, ${ }^{2}$ Graduate School of Planning, University of Puerto Rico at Río Piedras, ${ }^{3}$ Department of Environmental Sciences, University of Puerto Rico at Río Piedras, ${ }^{4}$ Center for Applied Tropical Ecology and Conservation, University of Puerto Rico at Río Piedras 
Fig. 1. Conceptual model for the study of factors that affect fluxes of energy and material at the scale of household.

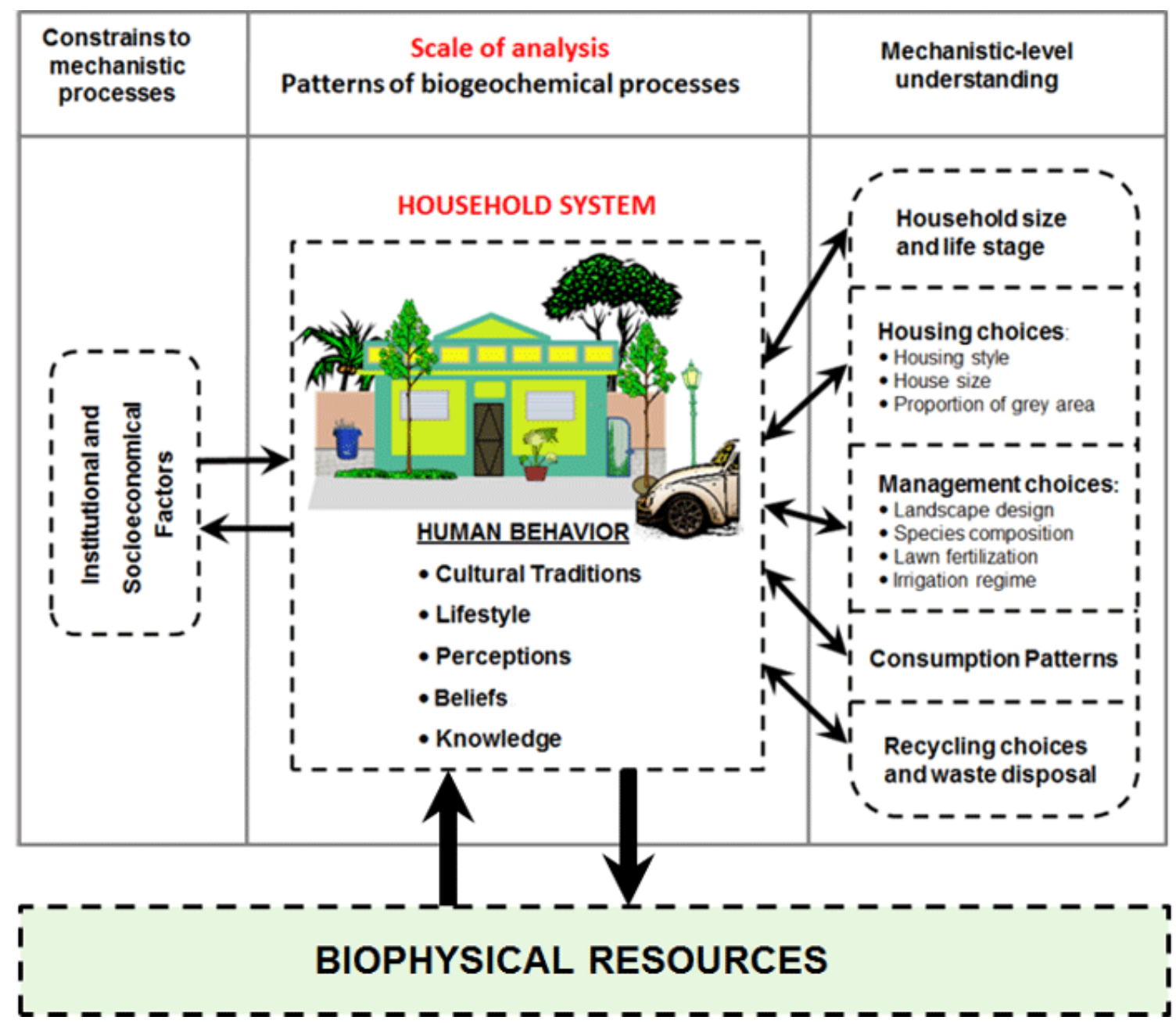

analysis to understand the effects of human behavior on the transfer of materials within urbanized ecosystems.

Since the mid-20th century, the urban area of San Juan has experienced an accelerated urbanization (Lugo et al. 2011) with development trends likely to compromise the quality of life for its residents. Today, the economy of Puerto Rico is based on the manufacturing industry and services, while local food production is substantially reduced (López-Marrero and Villanueva-Colón 2006). Food is one of the most essential materials imported into cities (Decker et al. 2000), and San Juan is not an exception. Land development in the lower elevation sectors of the island for residence or industrial built-up areas has substituted large areas of fertile soils with high agricultural production (López-Marrero and Villanueva-Colón 2006, Martinuzzi et al. 2007). On the other hand, economic trends, along with population growth trends that peaked in 2000 in the urban areas, have stimulated unprecedented patterns of imports and consumption (Carro-Figueroa 2002), which inevitably results in high rates of waste output (Wolman 1965). Currently, we have a macroscale level understanding on why policies adopted during the past for the industrialization of the island resulted in unparalleled patterns of imports, consumption, and waste production (Carro-Figueroa 2002). However, at the microscale level of the household unit, it is less clear what factors and human behaviors contribute to create those patterns.

In this study, we present a preliminary household-level characterization of activities that might influence the flow of materials and energy along the urban Río Piedras Watershed (RPWS) in Puerto Rico. The long-term purpose of this research is the understanding of mechanisms through which the dynamics of the household system along the RPWS might influence inflow, transformation, and storage of materials and energy. However, during this initial phase of the research we intended to expose some general patterns characterizing household activities related to food consumption and waste disposal. These kinds of activities are important components of the household system that we anticipate as likely having a large influence on materials and energy flow through the watershed. In this article we explore three 
aspects of household consumption and waste disposal across the RPWS: (1) the source of food consumed by households, (2) recycling activities, and (3) trends in the septic system for waste water disposal, which represent major outputs from the household.

\section{METHODS}

\section{Study sites}

The study areas are located within the RPWS, an urban watershed entirely contained within the San Juan metropolitan area of the island of Puerto Rico (Lugo et al. 2011). The RPWS includes parts of the municipalities of San Juan, Guaynabo, and Trujillo Alto and covers an area of $49 \mathrm{~km}^{2}$ (Lugo et al. 2011). The Río Piedras River originates in the Cupey sector at about $150 \mathrm{~m}$ of elevation and the river flows north for $16,000 \mathrm{~m}$ until it reaches the coast. The basin is located within two geographical regions of Puerto Rico, the Costal Lowlands Humid Alluvial Section and the Humid Northern Foot Hills Northeastern Cretaceous Section (Lugo et al. 2011). Extensive human modifications have changed the geomorphology of the river with large segments channelized, diverted, and even buried for the construction of urban infrastructure (Lugo et al. 2011). Mean annual rainfall in the watershed ranges from $1509 \mathrm{~mm}$ on the coast to $1755 \mathrm{~mm}$ upland, and mean annual temperatures for Río Piedras have been reported at $25.7^{\circ} \mathrm{C}$ (Lugo et al. 2011). The RPWS's ecosystem is classified as a subtropical moist forest zone according to Holdridge's life zone system (Holdridge 1967, Ewel and Whitmore 1973). Geological formations within the watershed include artificial fill, mangroves and swamp, alluvium deposit, limestone, and inclusive and volcaniclastic rocks, which cover more than $50 \%$ of its area (Webb and Gómez-Gómez 1998). The RPWS presents a land cover gradient that ranges from high-density urban built-up areas near the coast (lower watershed region) to forest cover around the headwaters (higher watershed region; Ramos-González et al. 2005). High resolution analysis of satellite images from 2002 by Ramos-González (2014) revealed that $66 \%$ of the north portion of the Municipality of San Juan is covered by impervious surfaces, whereas only $23 \%$ of impervious land covers the south portion. In the north portion, green infrastructure is much dispersed and individual residential yards comprise large proportions of it (Melendez-Ackerman et al, 2014, Ramos-González 2014).

This study was carried out at 6 of the 13 permanent study plots selected along the main channel of the Río Piedras River and its tributaries, which are used as a platform for the San Juan ULTRA exploratory project (Fig. 2; see Seguinot-Barbosa and Hernández-García 2010). Site selection was based on a general representation of the urban gradient of grey to green area coverage of the RPWS. General sampling framework considered population density ( $>100$ people per square mile; Fig. 2), income, and accessibility to the river or a tributary (Seguinot-Barbosa and Hernández-García 2010). For each of the point locations, we generated a circular buffer zone of $1 \mathrm{~km}$ radius and the resulting vector file was overlaid on an aerial photo for the San Juan Metro area (Fig. 2).

Among our study sites, Puerto Nuevo and Avenida Central are located in the lowest elevation ( 0 and 3 m.a.s.1, respectively) and more densely populated areas of the RPWS (U.S. Census Bureau 2010; Fig. 2). For the most part, areas within these two sites are characterized by high residential density (Fig. 2), typically with low-rise houses built in relatively small lots with high proportion of grey area coverage (Ramos-Santiago et al. 2014). The Puerto Nuevo site includes some of the oldest urban neighborhoods built by the mid-20th century (by year 1948) for the working middle class (Sepúlveda-Rivera 2004). The San Patricio study site (7 m. a.s.l) is also located in the lowest densely populated part of the watershed and also with a crowded residential built-up areas.

Fig. 2. Location of study sites along the Río Piedras Watershed. The graph represents total population (black bars) and total number of families (grey bars) by study site according to the U. S. Census Bureau (2010).

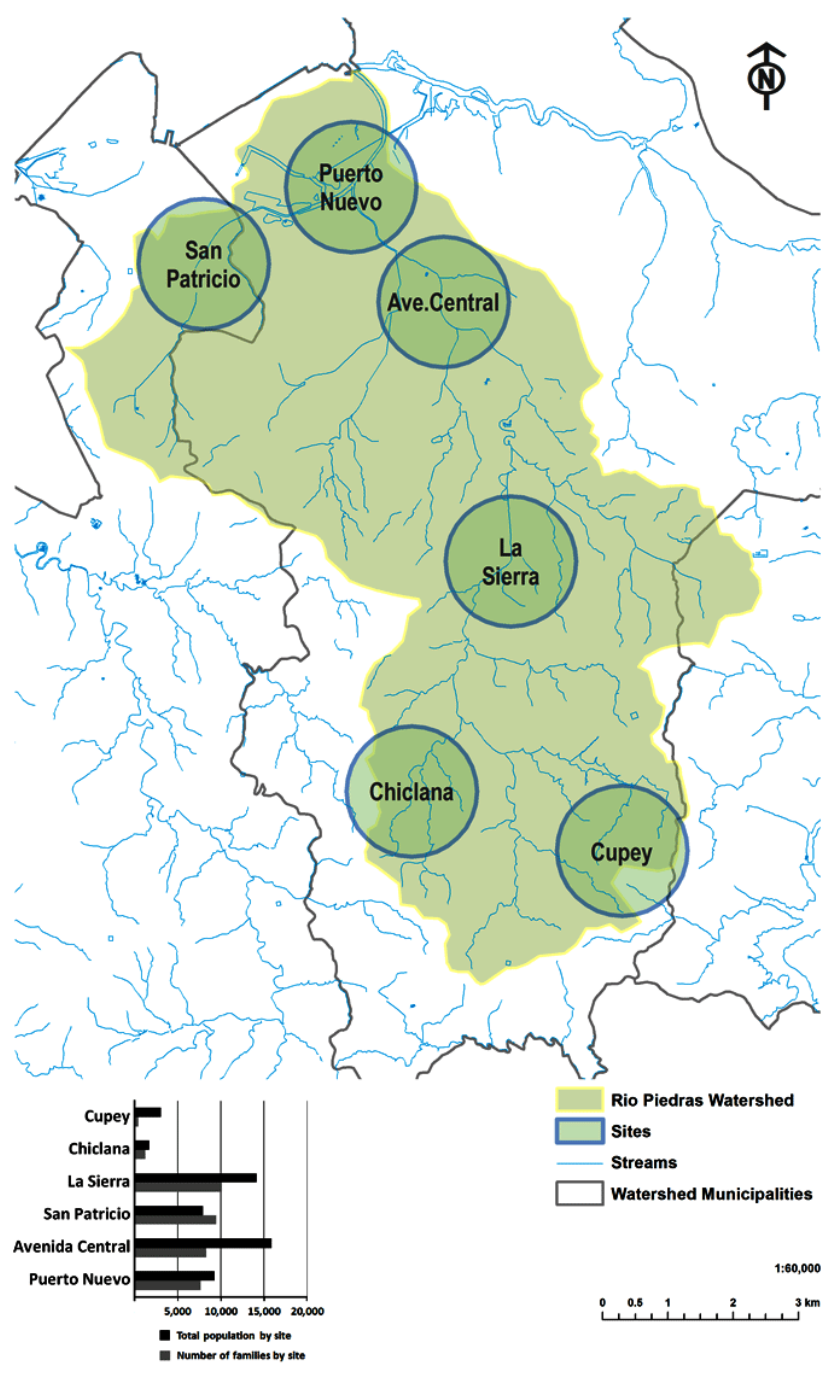

By contrast, residential structure is predominantly mixed in San Patricio, with a presence of single-family detached housing, townhouses, and high-rise condominiums. Although singlefamily housing generally includes private green areas, as in Puerto Nuevo and Avenida Central, high-rise condominiums comprise an aggregation of households with access to common services 
and spaces, including green areas that are usually managed by homeowner associations. Of all our study sites, San Patricio was the only one that presented larger family density than total population density (Fig. 2). La Sierra is located in the central region of the watershed at about 20 m.a.s.1, and together with Avenida Central, represent one of the highest population density sites of our study (Fig. 2), mostly characterized by neighborhoods with single-family detached housing. The Chiclana and Cupey sites, both located in the upland watershed (59 and 157 m.a.s.l, respectively) are mostly characterized by neighborhoods with relatively lower residential and population density (Fig. 2; U.S. Census Bureau 2010). In these neighborhoods, detached houses are usually built at the edge of curvilinear narrow streets, and contain a larger proportion of green areas, often interspaced by forested vegetation.

\section{Sampling design}

For the purpose of this study, households were surveyed within each circular buffer zone by randomly selecting 12 access roads containing at least 10 houses. From January to August 2011, person-to-person interviews were conducted at each household. The respondents were 21 years of age or older, and could be any member physically living in the unit for at least a year or more, whether a renter or an owner. Residents were personally interviewed using a 50-item questionnaire that included openended and choice questions with a variety of formats. Within each road we surveyed all possible households up to a maximum of 57 households per site. This sampling scheme resulted in a total of 440 households interviewed as follows: Puerto Nuevo $(\mathrm{N}=73)$, Avenida Central $(\mathrm{N}=81)$, San Patricio $(\mathrm{N}=69)$, La Sierra $(\mathrm{N}=$ 74), Chiclana $(\mathrm{N}=65)$, Cupey $(\mathrm{N}=78)$.

Questions used in this analysis included data on: source of food consumption, i.e., supermarket, corner markets, market squares, and residence yard; connection to the city sewerage system or septic tank as mechanism of waste water disposal; and recycling activities. The four categories of source of food consumption were not mutually exclusive. Therefore, we cannot quantify the amount of food obtained or purchased from each source, but our information provides the overall importance of the four consumption settings of food sources. Wastewater is usually considered any water adversely affected by human use. For the purpose of this study, we considered grey water as the wastewater generated from domestic activities associated with house cleaning, washing machines, showers, hand basins, and several other domestic uses. Septic water refers to wastewater that carries human waste, mostly as excretion.

We also conducted an analysis to estimate accessibility to commercial food service areas for residents in the study areas. We sought the addresses for food suppliers in the vicinity of study areas through local phone registries and supermarket websites ( $\mathrm{N}$ $=70$ ). These addresses were then geocoded to obtain their specific geographical location. A service area technique was utilized to obtain zones of $500 \mathrm{~m}$ and $1000 \mathrm{~m}$ coverage of walkable distance for each of the 70 facilities. These service areas represent the coverage that can be traveled by foot using the road network, which in urban areas is expected to be complemented with pedestrian infrastructure like sidewalks. The result of intersecting the service areas with U.S. census data is an estimate of the population within a walkable distance area from a commercial facility (Jiao et al. 2012). Because the service area technique takes into account the paths and street networks through which people can move, we decided that this technique would provide better estimates than the Euclidean buffer technique.

\section{RESULTS AND DISCUSSION}

\section{Source of food consumption}

Survey results reflected that food purchased from supermarkets was relatively widespread for households along the six surveyed areas (Fig. 3). Overall, 97\% of the 440 households surveyed purchased food from supermarkets. Corner markets were another source of food acquisition more frequently used by residents in neighborhoods such as Cupey, or by households located in the older urban neighborhoods of Puerto Nuevo and Avenida Central (Fig. 3). Because local food production in Puerto Rico has markedly declined during the last decades (López-Marrero et al. 2001), we assumed that supermarkets, mainly dominated by imported items, were a major source of food consumption for households. In addition, about $76 \%$ of food acquisition stores in Puerto Rico reported by the U.S. Census Bureau for the year 2011 were categorized as supermarkets and grocery stores. Likewise, $90 \%$ of full- and part-time paid employees and the annual payroll reported by the U.S. Census Bureau for the same year, also belonged to the category of supermarkets and grocery stores. Although the categories used by the U.S. Census Bureau are slightly different than those used in this study, they provide an idea of the importance of supermarkets as a source of food consumed in the island of Puerto Rico.

Fig. 3. Sources for food items consumed by households along the Río Piedras Watershed. The percentages are based on the 437 surveyed households and categories are not mutually exclusive.
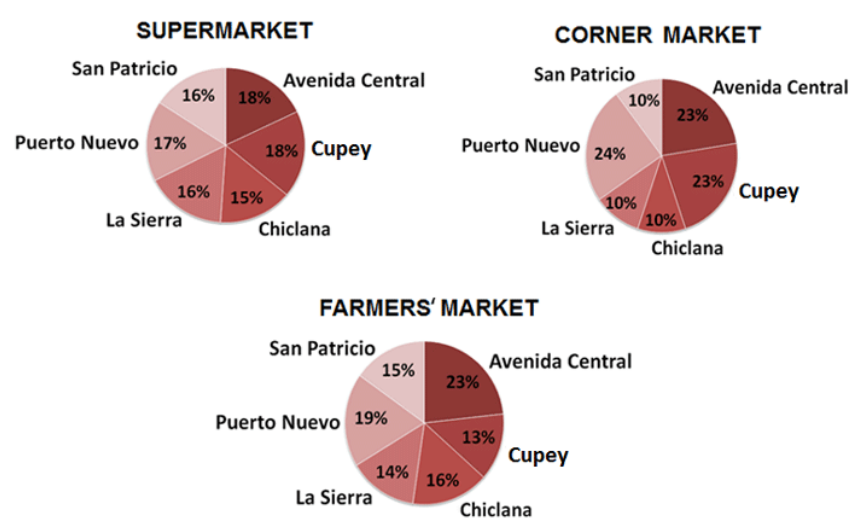

Food production from residential yards also provides another source of food acquisition for residents of several sectors of the RPWS. Food collected from yards was relatively important for most households in the Chiclana and Cupey neighborhoods, where more than $60 \%$ of residents responded positively to this question of our survey (Fig. 4). Homes in these neighborhoods of the upper portion of the watershed (Fig. 2) are more likely to have yards with considerable green space. Several residents from the Chiclana and Cupey neighborhoods pointed out that the land presently owned by them was previously part of a much larger 
farm probably operating since the Spanish colonial time. However, through time the farm had been segregated by selling or granting smaller lots of land to family members. Indeed, urbanization is a very recent phenomenon for this upper part of the RPWS (Martinuzzi et al. 2007), and food collection from residential yards seems to have a long tradition for residents of this area. Some of the most common items obtained from yards were banana, plantains, pigeon peas, avocado, various citric fruits, mango, papaya, and several species of yams, all part of the traditional food in Puerto Rico (Fig. 4).

Fig. 4. Percentage of households along the Río Piedras Watershed, represented by study site, responding that they obtained fruits and vegetables from their residential yards.
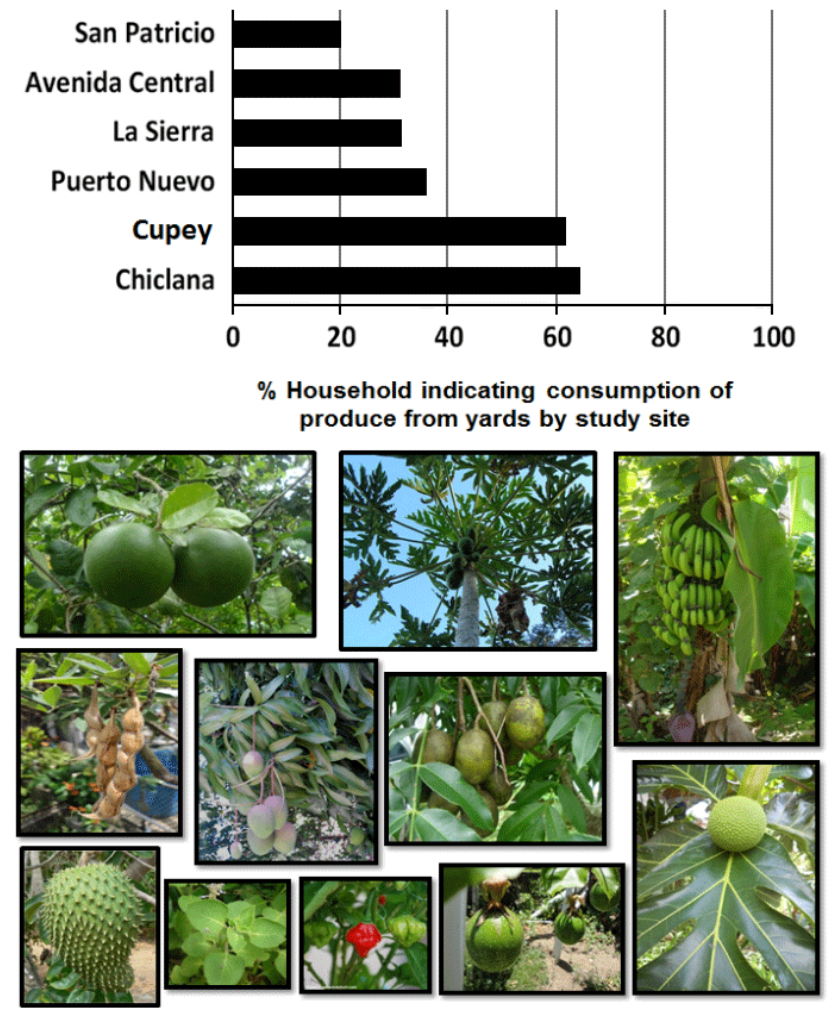

By contrast, in densely settled neighborhoods of the lower portions of the watershed, with a tendency for larger areas of impervious grey surfaces, fewer households indicated their practices of consuming food items cultivated in their yards. However, and remarkably enough, households obtaining produce from yards represented about $36 \%, 31 \%$, and $32 \%$ for Puerto Nuevo, Avenida Central, and La Sierra, respectively. In San Patricio though, only $20 \%$ of residents indicated practices of obtaining fruits and vegetables from yards. This lower proportion quantified for the San Patricio study site, might be partially explained by the relatively large number of aggregated households living in condominiums where decisions for common green areas are regulated through owners associations. Overall, despite the fact that supermarkets represented a widespread source of food acquisition, the urban food system across the RPWS also includes food locally produced in yards that are not sponsored by imports.
Access to commercial food acquisition is an important factor determining human behavior to consumption. For instance, the density of supermarkets or convenience stores along the RPWS follows the gradient of residential density, with a higher density of commercial stores observed in the lower parts of the watershed (Fig. 5). Consumption access in terms of distance to commercial stores also contrasts for residents across the RPWS. Areas of relatively high access exist along the lower, more northeastern part of the watershed, providing sites such as Puerto Nuevo some accessibility to commercial food sources. Even though the commercial accessibility level for the midwatershed areas seems limited, neighborhoods located in La Sierra are an exception. La Sierra presents the highest level of walkable accessibility to commercial sources for food acquisition (Fig. 6), with most of the study site covered in the $1000 \mathrm{~m}$ accessibility. Socioeconomically, La Sierra comprises higher than average income-level groups that also enjoy the best access to green areas (Santiago et al. 2014). The Chiclana sampling site also presents high accessibility to commercial food sources even though this site is part of the less densely populated area of the southern RPWS (Fig. 2). The high access obtained for Chiclana might be explained by the occurrence of a relatively small gated neighborhood (the Montehiedra neighborhood) comprising family groups with very high levels of income and acquisition power. The site with the least walkable access is Cupey, which comprises one of the socioeconomic groups with the lowest level of income (Santiago et al. 2014).

Fig. 5. Location of supermarkets and convenience stores. Addresses were obtained from local phone registries and supermarket chain websites $(\mathrm{N}=70)$. Some points are located within the RPWS whereas others are outside the boundaries of the watershed but were considered because they are near accessible areas to the study sites. All points selected are located within the San Juan Metro Area.

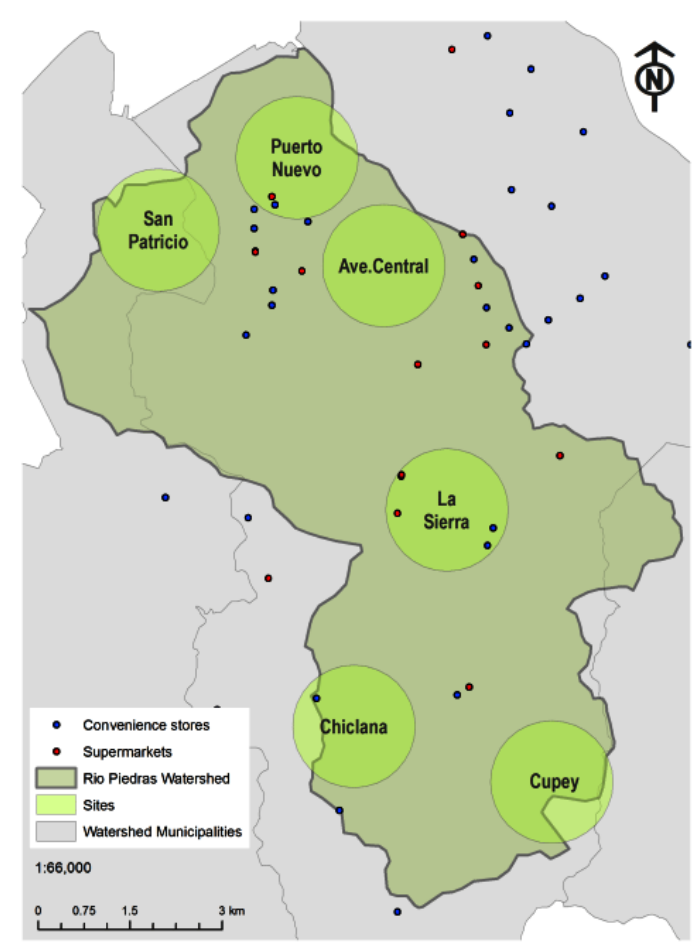


Fig. 6. Accessibility to supermarkets or convenience stores. A commercial service area technique was utilized to obtain buffer zones of $500 \mathrm{~m}$ and $1000 \mathrm{~m}$ coverage of walkable distance for each of the 70 facilities.

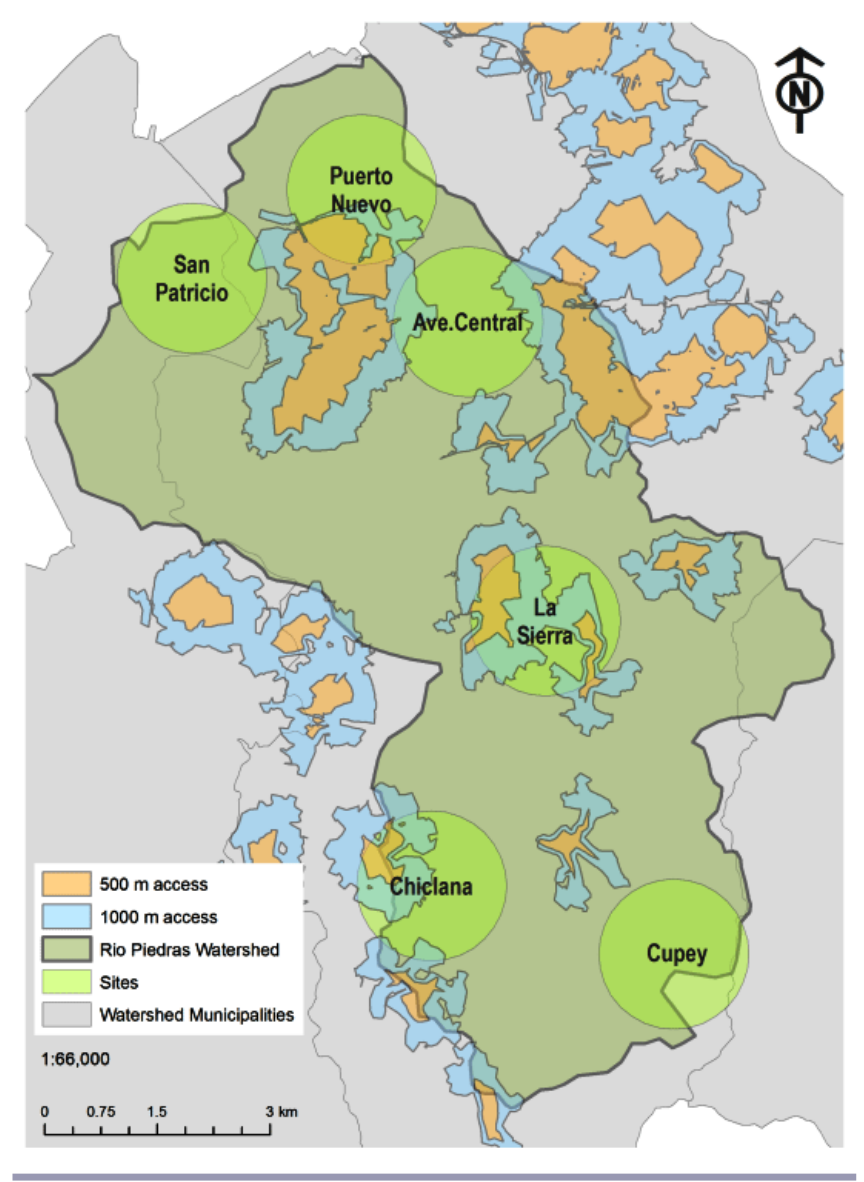

Waste disposal and recycling

Along the RPWS, the average percentage of household recycling was $65 \%$ with a standard deviation of 22 . This distribution indicates that although more than half of the households in the watershed appear to recycle, divergences in recycling activities among sites are relatively high. Indeed, recycling activities were mostly carried out by households from the San Patricio, Avenida Central, and La Sierra neighborhoods (Fig. 7), where more than $78 \%$ of the residents recycle. For instance, $93 \%$ of respondents in La Sierra indicated involvement in recycling activities (Fig. 7). By contrast, in Chiclana and Cupey, only $48 \%$ and $30 \%$, respectively, indicated participation in recycling activities (Fig. 7). Recycling requires significant individual effort, and for that reason recycling behavior is often encouraged where local programs make recycling easier (Derksen and Gartrell 1993). Indeed, in San Patricio, Avenida Central, and La Sierra neighborhoods the recycling programs sponsored by the municipalities of San Juan and Guaynabo encourage residents to recycle. In the upper portion of the watershed, where recycling collection programs are absent, much less recycling is conducted by residents (Fig. 7). Our results are consistent with those reported by Derksen and Gartrell (1993) in Canada that indicate that the most important determinant of the recycling behavior is access to structured, institutionalized programs that make recycling convenient.

Fig. 7. Percentage of households indicating involvement in recycling activities represented by study sites.

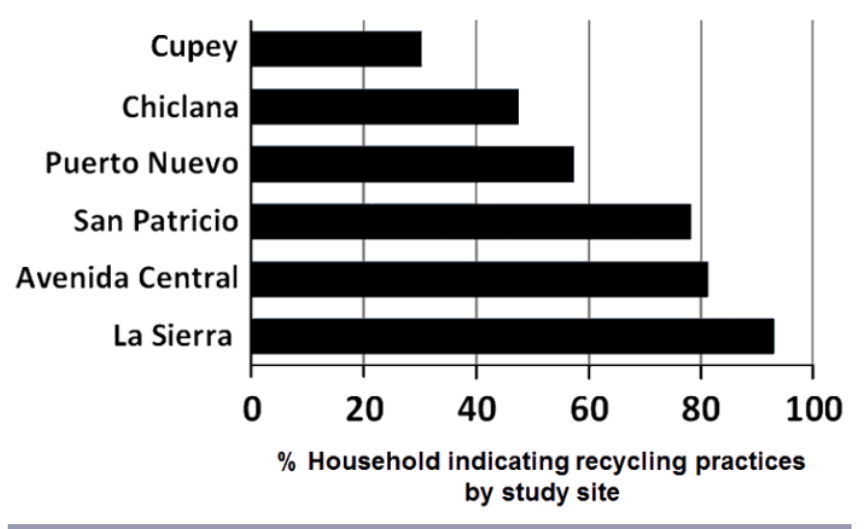

Wastewater disposal

Disposal of wastewater takes place either through the city sewerage system, septic tanks, or at the endpoint of discharge into the environment. Along the RPWS, household wastewater disposal examined through the interviews revealed a clear pattern. Most of the households (approximately 100\%) of high density, lower elevation portions of the RPWS, responded that they were connected to the sewer system (Fig. 8). By contrast, in neighborhoods of the higher elevation watershed, only 4 to $17 \%$ of respondents (Fig. 8) indicated that they were connected to the municipality's sewer system, while most of them indicated the use of septic thanks for septic water disposal. Actually, the $17 \%$ obtained for Chiclana can be lowered if we remove the highincome Montehiedra neighborhood described above. For these sites, nutrients and pollutants from the leftover water considered grey water migrate freely through impervious structures (Fig. 9) thus reaching soils and entering streams. Quiñones (2012) found that almost $41.5 \%$ of the residential customers of the Puerto Rico Aqueduct and Sewer Authority are not connected to the sewer system even though they are serviced for safe drinking water. Wastewater from these customers is discharged either in septic tanks or as grey water directly into the environment (Quiñones 2012).

According to the Quiñones' (2012) report, most septic tanks in Puerto Rico are inadequately built and recent studies conducted outside Puerto Rico (Harrison et al. 2012) had indicated that failure in the septic system is worsened as it ages. Improper management of septic water disposal has potential environmental consequences since these septic systems are a non-point source of nitrogen or other elements to local streams (Harrison et al. 2012). For instance, Harrison et al. (2012) pointed out that in the State of Maryland in the U.S., there are approximately 420,000 units of septic systems built up and they estimated that all septic systems together contribute to close to 1.6 million $\mathrm{kg}$ of $\mathrm{N}$ into the Chesapeake Bay each year. For the whole island of Puerto Rico, 
the estimate number of septic tanks is between 550,000 to 600,000 residential and 20,600, 3800, and 230 serving commercial, government, and industrial facilities, respectively (Quiñones 2012). Nitrogen loading from septic tanks in the headwater of the RPWS could also be a major source of pollutant of concern affecting downstream ecosystems such as the San Juan Bay Estuary (Lugo et al. 2011). The general spatial distribution of the sewage system along the RPWS in Figure 10, shows the wide extension of area in the upper portion of the watershed lacking sewerage connection. This pattern is substantiated by the results obtained from the interviews and certainly supports the idea that the absence of sewerage connection could have a significant effect on elemental inflow to local water bodies and downstream ecosystems.

Fig. 8. Percentage of households connected to a municipality's sewer system or to septic tank represented by study sites.

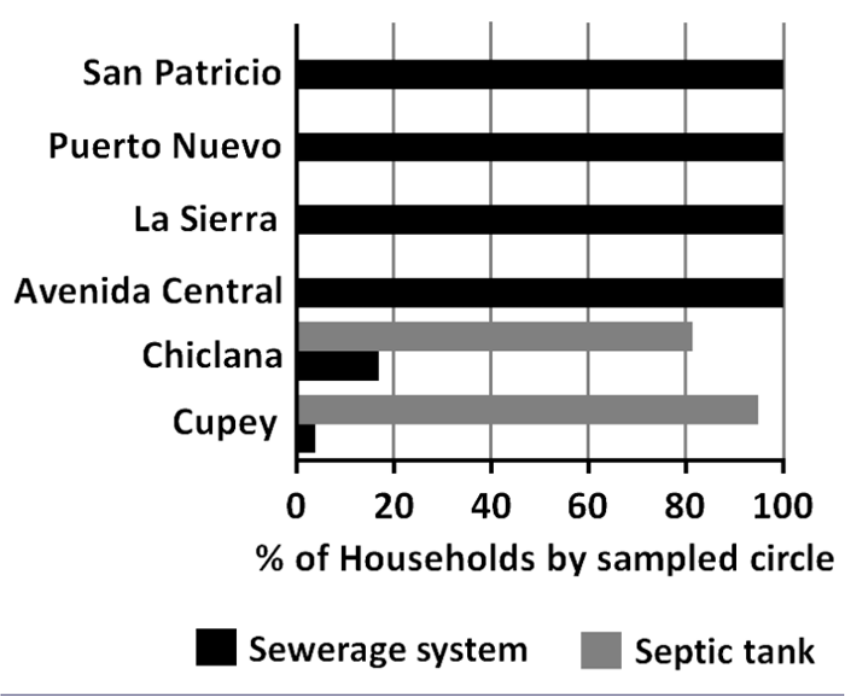

Fig. 9. Disposal of grey water generated from domestic activities. The pictures show grey water freely disposed through impervious structures and eventually reaching the environment. The photos were taken in areas of the upper portions of the Río Piedras Watershed.
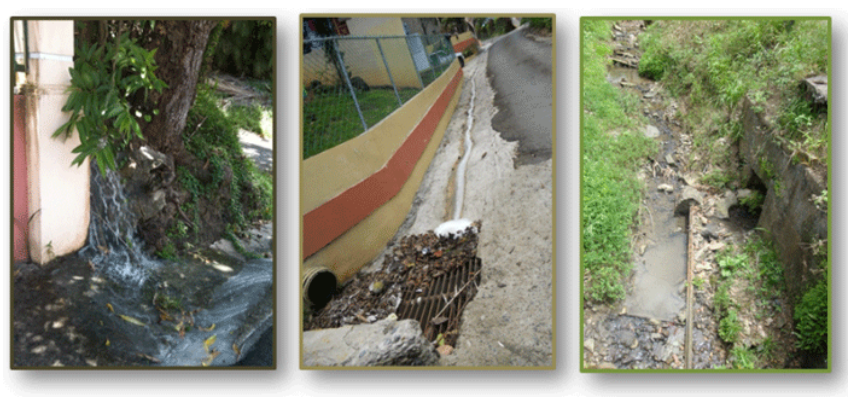

Fig. 10. Network distribution of the sewerage systems along the Río Piedras Watershed. Information obtained by the board of environmental planning of Puerto Rico.

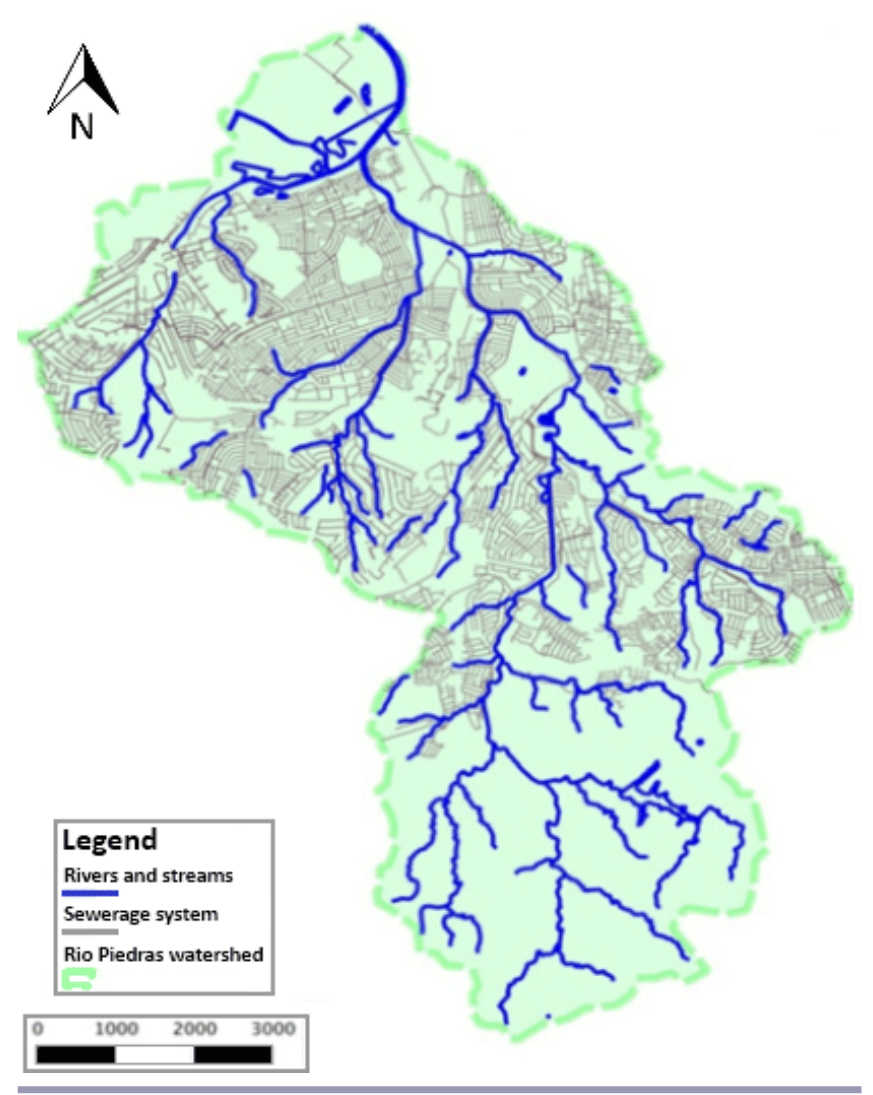

\section{CONCLUSIONS}

The notion of ecosystem processes driven by human behavior establishes a mechanism through which materials and energy fluxes could be understood in connection to human choices. Using the household as the unit of analysis embedded within the context of a watershed, allows for an evaluation of the link between human and natural system, while the watershed approach allows for evaluation of whole-ecosystem quantification of inputs and outputs (Likens 1992, Groffman et al. 2004, Ortiz-Zayas et al. 2006). Addressing processes at the household level might provide mechanistic understanding to the general input-output pattern observed in the whole watershed. In our initial characterization of the RPWS we found that consumption patterns, waste disposal, and wastewater management show contrasting differences between households located in the high-density, urban built-up region of the watershed versus those located in the lower residential density area of the upper watershed. Although almost all residents of the study sites located in the lower region of the RPWS discharged their wastewater through the city sewerage system and were usually engaged in recycling activities, they were also the more likely to have higher consumption rates of imported items obtained from supermarkets. Residents from these lower portions of the watershed had a larger proportion of grey 
coverage area, hence less green area access for planting edible plant species, but better access to supermarkets or convenience stores. On the other hand, residents from the upper regions of the watershed were more likely to consume produce from their own yards. However, these residents of the upper watershed were less engaged in recycling activities and the discharge of their wastewaters was directed to septic tanks or directly disposed into the environment without applying any treatment before water discharge. Wastewater represents an important output of materials from the household system (Baker et al. 2007); thus understanding the pathways for water disposal can provide mechanistic information about aspects of nutrient loading to the aquatic ecosystem from households.

Aside from the contrasting differences observed between households located in the lower portion versus the upper portion of the watershed, this study also revealed how high-level institutional decisions determine human attitudes toward the environment (Fig. 1). The implementation of municipal programs and the development of infrastructure for solid and liquid waste disposal determines how residential development might affect the natural environment along the RPWS. It is very likely that if public sewer services were extended to the upper region of the watershed, it might boost positive feedback for high-density urban development. However, it is also certain that water disposal through septic tank systems necessitates proper management of infrastructure to avoid the negative environmental effect resulting from various household activities. Local recycling behavior is also encouraged by high-level decisions through the implementation of programs that make recycling easier. Nonetheless, such programs are better endorsed in those areas with higher densities of urban population in municipalities with better access to economic resources that enable the delivery of local services and facilities to the local neighborhoods. We still need to gain a better understanding about patterns of gross food consumption of individual households along the RPWS. However, the fact that residents from the lower portions of the watershed have less green area access for planting edible plant species means that these dwellers are more likely to be net food buyers. Therefore, residential sprawling toward the upper portion of the watershed with ample areas of green cover (Ramos-González 2014), would imply land-use changes associated with urbanization thus reducing a potential source of local food production that could meet demands from areas with less food producing capacity. In addition, an increase in the flow of food from imported sources would likely have an effect on nutrient cycling, particularly in the $\mathrm{N}$ and $\mathrm{P}$ cycle and waste accumulation. It is clear though, that understanding the flow of material and energy of this tropical urban system is vital for insuring the maintenance of the natural environment.

Responses to this article can be read online at: http://www.ecologyandsociety.org/issues/responses. php/6118

\section{Acknowledgments:}

This work is a product of San Juan ULTRA exploratory project to study the urban ecosystem of the Rio Piedras Wartershed. San Juan ULTRAex was sponsored by the National Science Foundation under grant number 0948507. The Long-Term Ecological Research Project for the Luquillo Forest provided partial support for Diana Garcia-Montiel. The research was conducted in collaboration with the International Institute for Tropical Forestry, USDA Forest Service. We are grateful for the cooperation of many students and volunteers of the UPR system who helped in every stage of the research and in particular to the residents of San Juan, Guaynabo and Trujillo alto who made field data collection possible. Olga Ramos, USDA Forest Service, helped by providing general information about the study sites. We thank Dr. Ariel Lugo and Mildred Alayon for comments and editing on the manuscript. Finally, we also thank the two anonymous reviewers whose comments helped to improve this manuscript.

\section{LITERATURE CITED}

Baker, L. A., P. M. Hartzheim, S. E. Hobbie, J. Y. King, and K. C. Nelson. 2007. Effect of consumption choices on fluxes of carbon, nitrogen and phosphorus through households. Urban Ecosystems 10:97-117.

Carro-Figueroa, V. 2002. Agricultural decline and food import dependency in Puerto Rico: a historical perspective on the outcomes of postwar farm and food policies. Caribbean Studies 30(2):77-107.

Chowdhury, R. R., K. Larson, M. Grove, C. Polsky, and E. Cook. 2011. A multi-scalar approach to theorizing socio-ecological dynamics of urban residential landscapes. Cities and the Environment 4:1-18.

Codoban, N., and C. A. Kennedy. 2008. Metabolism of neighborhoods. Journal of Urban Planning and Development 134:21-31. http://dx.doi.org/10.1061/(ASCE)0733-9488(2008)134:1 (21)

Decker, E. H., S. Elliott, F. A. Smith, D. R. Blake, and F. S. Rowland. 2000. Energy and material flow through the urban ecosystem. Annual Review of Energy and Environment 25:685-740. http://dx.doi.org/10.1146/annurev.energy.25.1.685

Derksen, L., and J. Gartrell. 1993. The social context of recycling. American Sociological Review 58:434-442. http://dx.doi. org/10.2307/2095910

Ewel, J. J., and J. L. Whitmore. 1973. The ecological life zones of Puerto Rico and the U.S. Virgin Islands. U.S. Forest Service Research Paper ITF-108, Institute of Tropical Forestry, San Juan, Puerto Rico.

Groffman, P. M., N. L. Law, K. T. Belt, L. E. Band, and G. T. Fisher. 2004. Nitrogen fluxes and retention in urban watershed ecosystems. Ecosystems 7:393-403. http://dx.doi.org/10.1007/ s10021-003-0039-X

Grove, J. M., A. R. Troy, J. P. M. O’Neil-Dunne, W. R. Burch Jr., M. L. Cadenasso, and S. T. A. Pickett. 2006. Characterization of households and its implications for the vegetation of urban ecosystems. Ecosystems 9:578-597. http://dx.doi.org/10.1007/ s10021-006-0116-Z

Harrison, M., E. Stanwyck, B. Beckingham, O. Starry, B. Hanlon, and J. Newcomer. 2012. Smart growth and the septic tank: wastewater treatment and growth management in the Baltimore region. Land Use Policy 29:483-492. http://dx.doi.org/10.1016/j. landusepol.2011.08.007 
Holdridge, L. R. 1967. Life zone ecology. Tropical Science Center, San José, Costa Rica.

Jiao, J., A. V. Moudon, J. Ulmer, P. M. Hurvitz, and A. Drewnowski. 2012. How to identify food deserts: measuring physical and economic access to supermarkets in King County, Washington. American Journal of Public Health 102(10):e32-e39. http://dx.doi.org/10.2105/AJPH.2012.300675

Kaye, J. P., P. M. Groffman, N. B. Grimm, L. A. Baker, and R. V. Pouyat. 2006. A distinct urban biogeochemistry? Trends in Ecology and Evolution 21:192-199. http://dx.doi.org/10.1016/j. tree.2005.12.006

Kennedy, C., J. Cuddihy, and J. Engel-Yan. 2007. The changing metabolism of cities. Journal of Industrial Ecology 11:43-59. http://dx.doi.org/10.1162/jie.2007.1107

Likens, G. E. 1992. The ecosystem approach: its use and abuse. Excellence in Ecology, Book 3. Ecology Institute, Oldendorf/ Luhe, Germany.

Liu, J., G. C. Daily, P. R. Ehrlich, and G. W. Luck. 2003. Effects of household dynamics on resource consumption and biodiversity. Nature 421:530-533. http://dx.doi.org/10.1038/ $\underline{\text { nature } 01359}$

López-Marrero, T., M. Aide, and J. R. Thomlinson. 2001. Urban expansion and the loss of prime agricultural lands in Puerto Rico. Ambio 30:49-54.

López-Marrero, T., and N. Villanueva-Colón. 2006. Atlas ambiental de Puerto Rico. Editorial Universidad de Puerto Rico, San Juan, Puerto Rico.

Lugo, A. E., O. Ramos-González and C. Rodríguez-Pedraza. 2011. Description of the Rio Piedras River Watershed and its surrounding environment. International Institute of Tropical Forestry, U.S. Forest Service, Jardín Botánico Sur, San Juan, Puerto Rico.

Martinuzzi, S., W. A. Gould, and O. M. Ramos-González. 2007. Land development, land use, and urban sprawl in Puerto Rico integrating remote sensing and population census data. Landscape and Urban Planning 79:288-297. http://dx.doi. org/10.1016/j.landurbplan.2006.02.014

Melendez-Ackerman, E. J., R. Santiago-Bartolomei, C. P. VilaRuiz, L. E. Santiago, D. García-Montiel, J. C. Verdejo Ortiz, H. Manrique-Hernández and E. Hernandez-Calo 2014. Socioeconomic drivers of yard sustainable practices in a tropical city. Ecology and Society, in press.

Ortiz-Zayas, J. R., E. Cuevas, O. L. Mayol-Bracero, L. Donoso, I. Trebs, D. Figueroa-Nieves, and W. H. McDowell. 2006. Urban influences on the nitrogen cycle in Puerto Rico. Biogeochemistry 79:109-133. http://dx.doi.org/10.1007/s10533-006-9005-y

Pickett, S. T. A., M. L. Cadenasso, J. M. Grove, C. H. Nilon, R. V. Pouyat, W. C. Zipperer, and R. Costanza. 2001. Urban ecological systems: linking terrestrial, ecological, physical, and socioeconomic components of metropolitan areas. Annual Review of Ecology and Systematic 32:127-157. http://dx.doi. org/10.1146/annurev.ecolsys.32.081501.114012
Quiñones, F. 2012. Impacto Ambiental de Pozos Sépticos en Puerto Rico y su Diseño y Control. Dimensión, Revista del Colegio de Ingenieros y Agrimensores de Puerto Rico 1:16-22.

Ramos-González, O. M. 2014. The green areas of San Juan, Puerto Rico. Ecology and Society, in press

Ramos-González, O. M., C. D. Rodríguez-Pedraza, A. E. Lugo, and B. Edwards. 2005. Distribution of forests and vegetation fragments in the San Juan metropolitan area. Page 111 in T. W. Zimmerman, V. Combie, C. C. Clarke, editors. Proceedings of the 9th Annual Urban and Community Forestry Conference: Managing the Caribbean Urban and Community Forest. June 14-18. University of the Virgin Islands, Cooperative Extension Service, St. John, U.S. Virgin Islands.

Ramos-Santiago, L., L. Enrique, L. Villanueva-Cubero, L. E. Santiago-Acevedo, and Y. N. Rodriguez-Melendez. 2014. Green area loss in San Juan's inner-ring suburban neighborhoods: a multidisciplinary approach to analyzing green/gray area dynamics. Ecology and Society, in press.

Santiago, L. E., J. C. Verdejo Ortiz, R. Santiago-Bartolomei, E. J. Melendez-Ackerman, and D. C. Garcia-Montiel. 2014. Uneven access and underutilization of ecological amenities in urban parks of the Rio Piedras Watershed. Ecology and Society, in press.

Seguinot-Barbosa, J., and R. Hernández-García. 2010. Metodología para el diseño de muestreo socio-ambiental en la Cuenca del Río Piedras: San Juan, Puerto Rico. Instituto Nacional de Estadística y Geografía, Aguascalientes, México. [online] URL: http://sanjuanultra.org/files/2012/05/Seguinot-metodo-GISsampling-Rio-piedras.pdf

Sepúlveda Rivera, A. 2004. Puerto Rico urbano. Atlas histórico de la ciudad puertorriqueña. Vol. 1. Centro de Investigaciones CARIMAR and Departamento de Transportación y Obras Públicas, San Juan, Puerto Rico.

U.S. Census Bureau. 2010. Population estimates: Puerto Rico intercensal estimates (2000-2010): Annual population estimates. U.S. Census Bureau, Washington, D.C., USA. [online] URL: http://www.census.gov/popest/data/intercensal/puerto_rico/pr2010. $\underline{\mathrm{html}}$

Webb, R. M. T., and F. Gómez-Gómez. 1998. Synoptic survey of water quality and bottom sediments, San Juan Bay estuary system, Puerto Rico, December 1994-July 1995. Water Resources Investigations Report 97-4144. U.S. Department of the Interior, U.S. Geological Survey, San Juan, Puerto Rico.

Wolman, A., 1965. The metabolism of cities. Scientific American 213:178-190. http://dx.doi.org/10.1038/scientificamerican0965-178 